\title{
A new cockroach (Blattodea, Corydiidae) with pectinate antennae from mid-Cretaceous Burmese amber
}

\author{
Guanyu Chen', Lifang Xiao', Junhui Liang², Chungkun Shih ${ }^{1,3}$, Dong Ren' \\ I College of Life Sciences and Academy for Multidisciplinary Studies, Capital Normal University, 105 Xisan- \\ huanbeilu, Haidian District, Beijing 100048, China 2 Tianjin Natural History Museum, 31 Youyi Road, \\ Hexi District, Tianjin, 300203, China 3 Department of Paleobiology, National Museum of Natural History, \\ Smithsonian Institution, Washington, DC, 20013-7012, USA
}

Corresponding author: Dong Ren (rendong@mail.cnu.edu.cn)

Academic editor: Fred Legendre | Received 11 April 2021 | Accepted 24 August 2021 | Published 24 September 2021

http://zoobank.org/FF74D1EF-11A4-4D51-919F-ODB6CF7E25C3

Citation: Chen GY, Xiao LF, Liang JH, Shih CK, Ren D (2021) A new cockroach (Blattodea, Corydiidae) with pectinate antennae from mid-Cretaceous Burmese amber. ZooKeys 1060: 155-169. https://doi.org/10.3897/ zookeys. 1060.67216

\begin{abstract}
A new species of fossil cockroach, Fragosublatta pectinata gen. et sp. nov., is described from mid-Cretaceous Burmese amber. The new species is assigned to the family Corydiidae based on the following combination of characters: pronotum with tubercles, tegmina obovate with smallish anal region and spinules on the antero-ventral margin of the front femur (type C1). The new species is the second reported cockroach with ramified antennae. This finding broadens the diversity of Blattodea in mid-Cretaceous Burmese amber and provides further evidence of convergent evolution for antennal structures among different insect lineages.
\end{abstract}

\section{Keywords}

Convergent evolution, Myanmar, new genus, new species, pectinate antenna, sexual dimorphism, systematic palaeoentomology

\section{Introduction}

Blattodea is an order of insects consisting of cockroaches and termites (Inward et al. 2007; Zhao et al. 2019). Up to date, about 5000 extant cockroach species and 1500 fossil species have been documented (Liang et al. 2019; Li et al. 2020).

Copyright Guanyu Chen et al. This is an open access article distributed under the terms of the Creative Commons Attribution License (CC BY 4.0), which permits unrestricted use, distribution, and reproduction in any medium, provided the original author and source are credited. 
Diverse insects have been documented from the mid-Cretaceous Burmese (Myanmar) amber recently (Ross 2020, 2021). An ecosystem with a humid climate in the midCretaceous enriched the diversity of cockroach species (Liang et al. 2019). Up to now, 11 families, 28 genera and 36 species of cockroaches in Burmese amber have been documented as shown in Table 1 (Ross 2021). However, only two extinct species of Corydiidae have been reported in Burmese amber so far. The specimens in Burmese amber give us an opportunity to better understand the morphological characters of ancient insects.

Antennae of insects harbor the functions of smell, taste and other senses (Schneider 1964). Some insects have evolved ramified antennae, ranging from forms that are pectinate or bipectinate to plumose (Gao et al. 2016). As documented in the fossil record, 26 insect species in six orders, mostly males, have preserved ramified antennae, e.g., Atefia rasnitsyni (Hymenoptera), Palaeopsilotreta burmanica (Trichoptera), Vitimopsyche pectinella (Mecoptera), Ol xiai (Blattodea), Oligopsychopsis penniformis (Neuroptera), Cerophytum albertalleni (Coleoptera), as summarized in Table 2. Nevertheless, cockroaches with ramified antennae are very rare, with only one reported species (Olxiai, male) in Olidae having bipectinate antennae (Vršanský and Wang 2017).

Herein, we describe a new genus and species, Fragosublatta pectinata gen. et sp. nov., assigned to Corydiidae. This new finding broadens the diversity of Blattodea in mid-Cretaceous Burmese amber, clarifies the varieties of their antennal morphology, and suggests a potential sexual dimorphism for these cockroaches.

\section{Material and methods}

The type specimen was collected from deposits in the Hukawng Valley of Kachin in northern Myanmar, approximately $100 \mathrm{~km}$ southwest of the village of Tanai. The age of Myanmar amber is documented as $98.79 \pm 0.62 \mathrm{Mya}$, in the mid-Cretaceous (Grimaldi and Ross 2017). Myanmar amber pieces have preserved abundant specimens of plants, insects and other invertebrates. The latest comprehensive list of insect taxa from Myanmar amber comprises 28 orders, 421 families, 975 genera and 1383 species (Ross 2020, 2021). The type specimen is housed in the Key Laboratory of Insect Evolution and Environmental Changes, College of Life Sciences and Academy for Multidisciplinary Studies, Capital Normal University, Beijing, China (CNUB; Dong Ren, Curator).

The new specimen was examined and photographed using a Leica M205C dissecting microscope with a Leica DFC450 digital camera system. The detailed and enlarged photos were taken by using a Nikon SMZ 25 microscope with a Nikon DS-Ri 2 digital camera system. Cool white transmitted light from microscope's LED illuminators passed through the specimen from the top, and cool white light, emitted from double optical fibers, irradiated the specimen from two sides simultaneously. Line drawings were prepared by using Adobe Illustrator CC and Adobe Photoshop CS5 graphics software.

Morphological terminology largely follows Roth (2003); venational terms follow Snodgrass (1935), with further interpretations by Smart (1951) and Li and Wang (2017) as a frame of reference. 
Table I. Records of cockroaches described in Burmese amber.

\begin{tabular}{|c|c|c|}
\hline Family & Species & Reference \\
\hline \multirow[t]{2}{*}{ Blattulidae } & Huablattula hui & Qiu et al. 2019a \\
\hline & Huablattula jiewenae & Qiu et al. 2019a \\
\hline \multirow[t]{2}{*}{ Mesoblattinidae } & Spinaeblattina myanmarensis & Hinkelman 2019 \\
\hline & Mesoblatta maxi & Hinkelman and Vršanská 2020 \\
\hline Raphidiomimidae & Raphidiomimula burmitica & Grimaldi and Ross 2004 \\
\hline \multirow[t]{4}{*}{ Liberiblattinidae } & Spongistoma angusta & Sendi et al. 2020a \\
\hline & Stavba babkaeva & Vršanský et al. 2019 \\
\hline & Stavba vrsanskyi & Chen et al. 2020 \\
\hline & Stavba jarzembowskii & Li et al. 2020 \\
\hline Olidae & Olxiai & Vršanský and Wang 2017 \\
\hline \multirow[t]{10}{*}{ Alienopteridae } & Vzrkadlenie miso & Sendi et al. 2020a \\
\hline & Formicamendax vršanskýi & Hinkelman 2020 \\
\hline & Teyia branislav & Vršanský et al. 2018a \\
\hline & Teyia huangi & Vršanský et al. 2018a. \\
\hline & Meilia jinghanae & Vršanský et al. 2018a \\
\hline & Caputoraptor vidit & Vršanský et al. 2018a \\
\hline & Alienopterix ocularis & Vršanský et al. 2018a \\
\hline & Alienopterix smidovae & Vršanský et al. 2021 \\
\hline & Alienopterix mlynskyi & Vršanský et al. 2021 \\
\hline & Nadveruzenie postava & Vršanský et al. 2021 \\
\hline \multirow[t]{5}{*}{ Umenocoleidae } & Jantaropterix ellenbergeri & Mlynský et al. 2019 \\
\hline & Cratovitisma bechlyi & Podstrelená and Sendi 2018 \\
\hline & Perspicuus pilosus & Koubová and Mlynský 2020 \\
\hline & Perspicuus vršanský & Koubová and Mlynský 2020 \\
\hline & Antophiloblatta hispida & Sendi et al. 2020a \\
\hline \multirow[t]{4}{*}{ Blattidae } & Cretaperiplaneta kaonashi & Qiu et al. 2020 \\
\hline & Balatronis cretacea & Šmídová and Lei 2017 \\
\hline & Bubosa poinari & Šmídová. 2020 \\
\hline & Spinka fussa & Vršanský et al. 2018b \\
\hline \multirow[t]{2}{*}{ Corydiidae } & Nodosigalea burmanica & Li and Huang 2018 \\
\hline & Magniocula apiculata & Qiu et al. 2019b \\
\hline \multirow[t]{3}{*}{ Nocticolidae } & Mulleriblattina bowangi & Sendi et al. 2020b \\
\hline & Crenocticola svadba & Sendi et al. 2020b \\
\hline & Crenocticola burmanica & Li and Huang 2019 \\
\hline Manipulatoridae & Manipulator modificaputis & Vršanský and Bechly 2015 \\
\hline Incertae sedis & Cercoula brachyptera & $\mathrm{Li}$ and Huang 2021 \\
\hline
\end{tabular}

\section{Systematic palaeoentomology}

\section{Order Blattodea Brunner von Wattenwyl, 1882 Family Corydiidae Saussure \& Zehntner, 1893}

\section{Genus Fragosublatta Chen, Shih \& Ren, gen. nov.} http://zoobank.org/97CB1AFA-A97C-4A12-AA36-CD3070D3F840

Diagnosis. (male only). Sc field narrow (about a third of the width of the $\mathrm{R}$ region) with Sc short and branched. CuA almost straight with comb-like branches. CuP sharply curved. The first and the second hind tarsomeres with no plantulae but with spines. Cercus monoliform. 
Etymology. Fragosublatta is a combination of fragosus (Latin for fractured), referring to the fractured pronotum, and the generic name of Blatta. Gender is feminine.

Remarks. The new species is assigned to the family Corydiidae based on these characters: pronotum with tubercles, tegmina obovate with smallish anal region and spinules on the antero-ventral margin of the front femur (type C1). The new genus is differentiated from other extinct genera mainly by the forewing and legs: $\mathrm{CuA}$ with comb-like branches and the first and the second hind tarsomeres apparently lacking plantulae but with spines. Besides, the subgenital plate of the new species is almost symmetrical, which is similar to Nodosigalea burmanica (Li \& Huang, 2018), but the new species has comb-like $\mathrm{CuA}$ branches to justify the erection of a new genus.

\section{Fragosublatta pectinata Chen, Shih \& Ren, sp. nov.} http://zoobank.org/0576681A-20FA-46D6-8ED9-6003EA0F69DB Figs $1-4$

Type material. Holotype: CNU-BLA-MA2015001, a male specimen. The specimen was preserved in amber at an angle. Most of the insect body parts are preserved, but major parts of the head and all left tibiae and tarsi are missing. The pronotum and the left forewing are fractured.

Locality and horizon. Hukawng Valley, Kachin State, northern Myanmar; lowermost Cenomanian, mid-Cretaceous.

Diagnosis. As for the genus due to monotype.

Description. Medium-sized brown cockroach, body narrow and flattened, overall body length $8.21 \mathrm{~mm} /$ width $2.97 \mathrm{~mm}$ (Fig. 1A, B). Major parts of head not preserved. Eyes and labial palps invisible. Mandibles with two sharp teeth preserved (Fig. 3A). Only four maxillary palps preserved (total length $1.02 \mathrm{~mm}$ ), with terminal palpomere oval in shape. Sensilla on palps dense and small, $<0.01 \mathrm{~mm}$ wide. Both antennae detached from head and missing some antennomeres (Fig. 2A, B); antennae with 19 and 40 antennomeres respectively; length of antennae slightly shorter than forewing length; both antennae with comb-like extensions at end of each flagellomere. Basal flagellomeres simple, thick and short, medial 20 successive flagellomeres pectinate and apical 13 flagellomeres simple (Fig. 3). Longest comb-like extension of pectinate flagellomeres $0.19 \mathrm{~mm}$. Antennomeres roundish to cylindrical with widest base of $0.13 \mathrm{~mm}$. Pronotum (length $2.15 \mathrm{~mm} /$ width $1.84 \mathrm{~mm}$, as preserved) with dense tubercles, nearly vaulted (Fig. 1C), partly sclerotized and melanized, anterior margin covered with obvious hairs. Scutellum distinct, long and wide (ca 0.75/ca1.18 mm).

Forewing obovate, overlapping each other and completely covering abdomen. Left forewing overlapping right forewing. Right forewing $7.7 \mathrm{~mm}$ long, anterior margin arched, apex rounded (Fig. 2C). Right forewing costa $2.13 \mathrm{~mm}$ long. Sc field narrow, slightly curved, dichotomized with two veins not meeting margin, occupying about one third of forewing length. $\mathrm{R}$ regularly branched. $\mathrm{M}$ with only two branches. $\mathrm{CuA}$ almost straight, posterior-most veins comb-like, up to nine veins preserved. $\mathrm{CuP}$ 

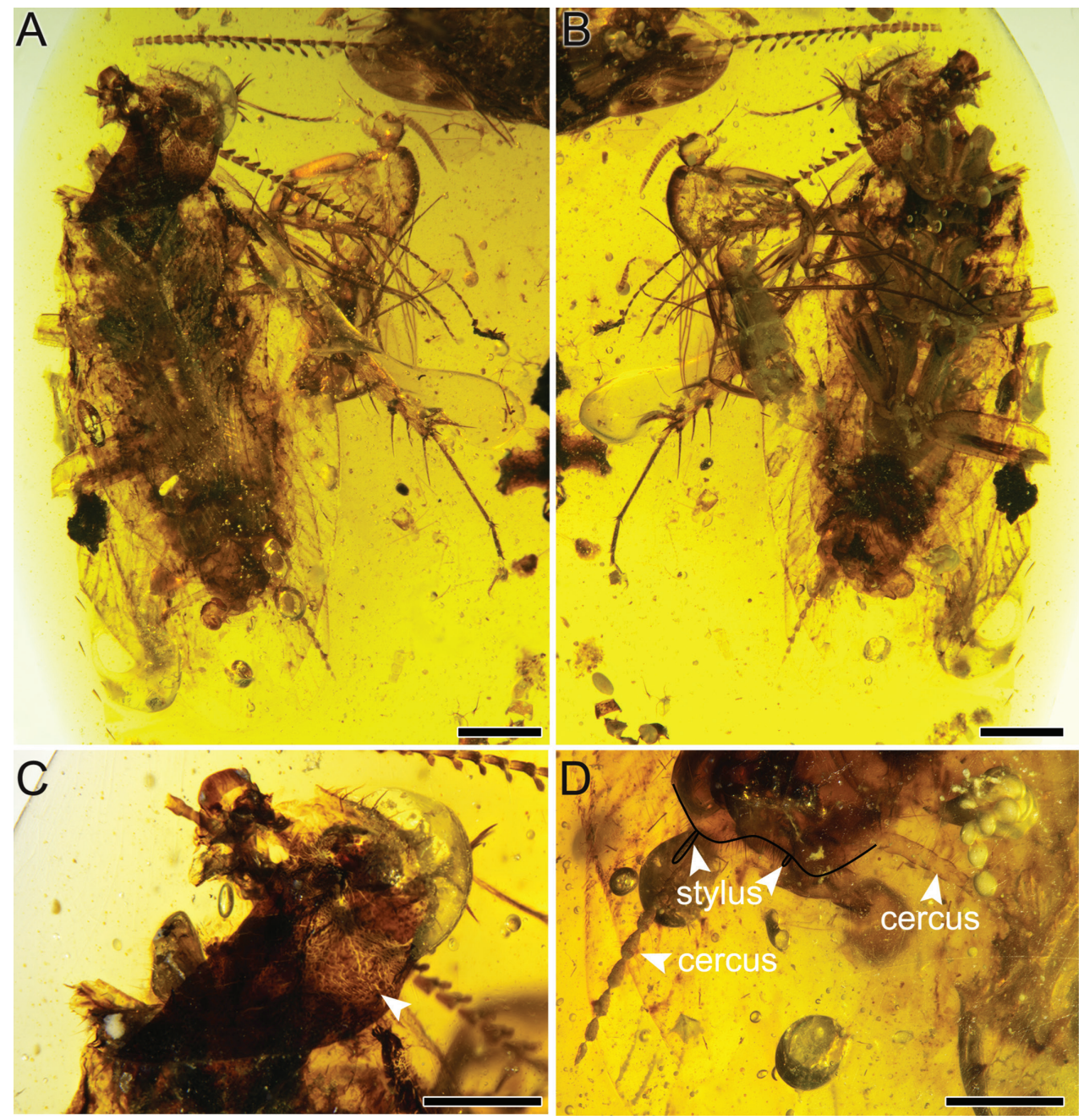

Figure I. Holotype of Fragosublatta pectinata gen. et sp. nov. CNU-BLA-MA2015001 A photograph of habitus in dorsal view $\mathbf{B}$ photograph of habitus in ventral view $\mathbf{C}$ photograph of the pronotum, with arrowhead indicating the tubercles $\mathbf{D}$ photograph of the moniliform cercus and asymmetrical stylus. Scale bars: $1.0 \mathrm{~mm}(\mathbf{A}, \mathbf{B}), 0.2 \mathrm{~mm}(\mathbf{C}, \mathbf{D})$.

sharply curved. Most of clavus area sclerotized, anal area obviously smallish, with seven veins. Left forewing $7.37 \mathrm{~mm}$ long, damaged basally. $\mathrm{R}$ with six visible branches. $\mathrm{M}$ with only two branches preserved. CuA richly branched with distinct intercalary veins. $\mathrm{CuP}$ simple, probably with only two and relatively straight A veins. Hind wing membranous, transparent. $\mathrm{R}$ branched, with 6-7 visible veins, reaching wing margin.

From fore legs to hind legs gradually stronger. Fore coxa short and wide (length $0.76 \mathrm{~mm} /$ width $0.37 \mathrm{~mm}$ ). Femur with carination, $1.15 \mathrm{~mm}$ long and $0.28 \mathrm{~mm}$ wide, antero-ventral margin of fore femur with even spinules (type $\mathrm{C} 1$ according to Roth 2003), terminal spine $0.36 \mathrm{~mm}$ long, slightly curved (Fig. 4A). Tibia (length $0.73 \mathrm{~mm} /$ 
A

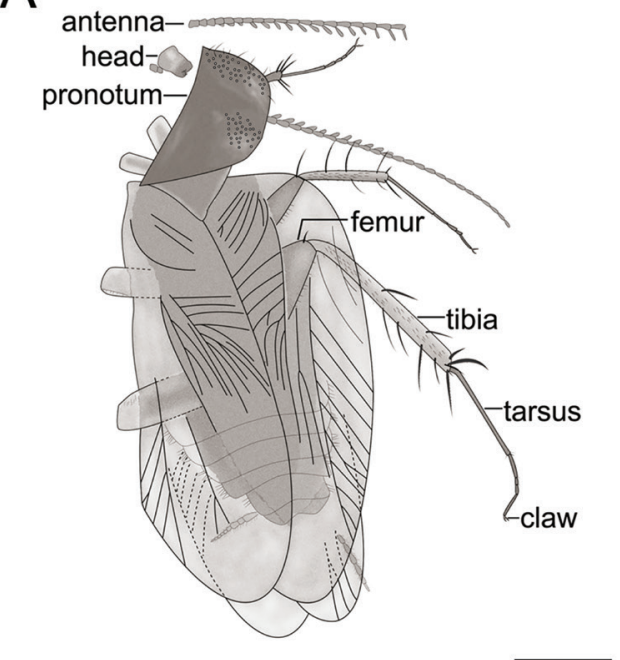

B

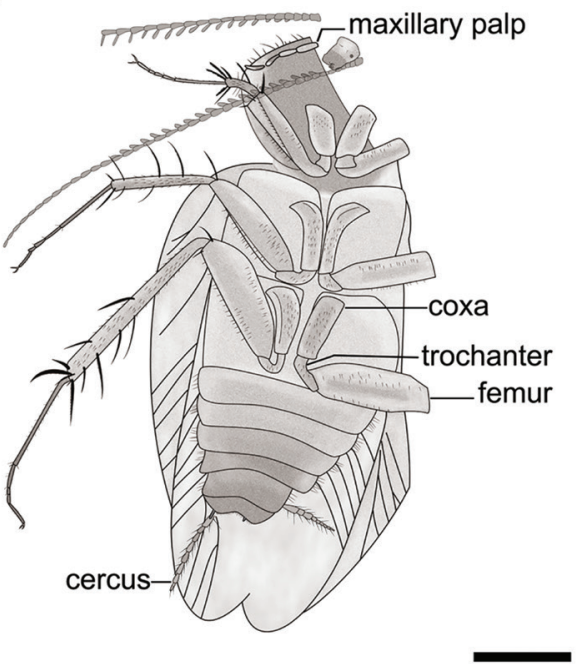

C

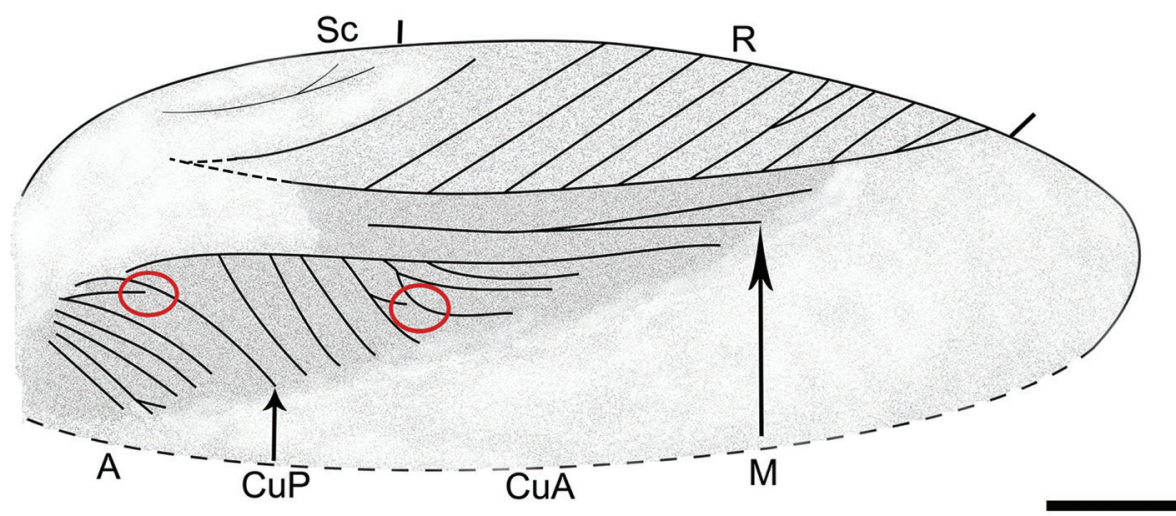

Figure 2. Holotype of Fragosublatta pectinata gen. et sp. nov. CNU-BLA-MA2015001 A line drawing in dorsal view $\mathbf{B}$ line drawing in ventral view $\mathbf{C}$ line drawing of the right forewing, with circles indicating the incomplete veins. Scale bars: $1.0 \mathrm{~mm}(\mathbf{A}, \mathbf{B}), 0.5 \mathrm{~mm},(\mathbf{C})$.

width $0.17 \mathrm{~mm}$ ) typical in Corydiidae, with long spines, most of spines with serrations (Fig. 4B). Tarsi five-segmented (length $0.76 / 0.18 / 0.14 / 0.13 / 0.23 \mathrm{~mm}$ ), with a total of $1.44 \mathrm{~mm}$ long and $0.04 \mathrm{~mm}$ wide. Claw symmetrical (Fig. 4A), strong, $0.18 \mathrm{~mm}$ long, arolium absent. Mid coxa with carination, $1.04 \mathrm{~mm}$ long and $0.2 \mathrm{~mm}$ wide. Trochanter comparatively longer (length $0.39 \mathrm{~mm}$ ). Femur $1.87 \mathrm{~mm}$ long and $0.44 \mathrm{~mm}$ wide with two rows of spinules. Terminal spine not curved distinctly, $0.48 \mathrm{~mm}$ long (Fig. 4C). Tibia approximately as long as femur, $1.51 \mathrm{~mm}$ long and $0.17 \mathrm{~mm}$ wide, with seven spines. Tarsi $2.03 \mathrm{~mm}$ long and $0.05 \mathrm{~mm}$ wide, first tarsomere longest (length $0.68 \mathrm{~mm}$ ), terminal tarsomere with symmetrical claws (length $0.13 \mathrm{~mm}$ ). Hind coxa $1.2 \mathrm{~mm}$ long with obvious carination, narrowing from top to bottom. Hind trochanter $0.4 \mathrm{~mm}$ long and $0.6 \mathrm{~mm}$ wide. Femur strong (length $2.03 \mathrm{~mm} /$ width 


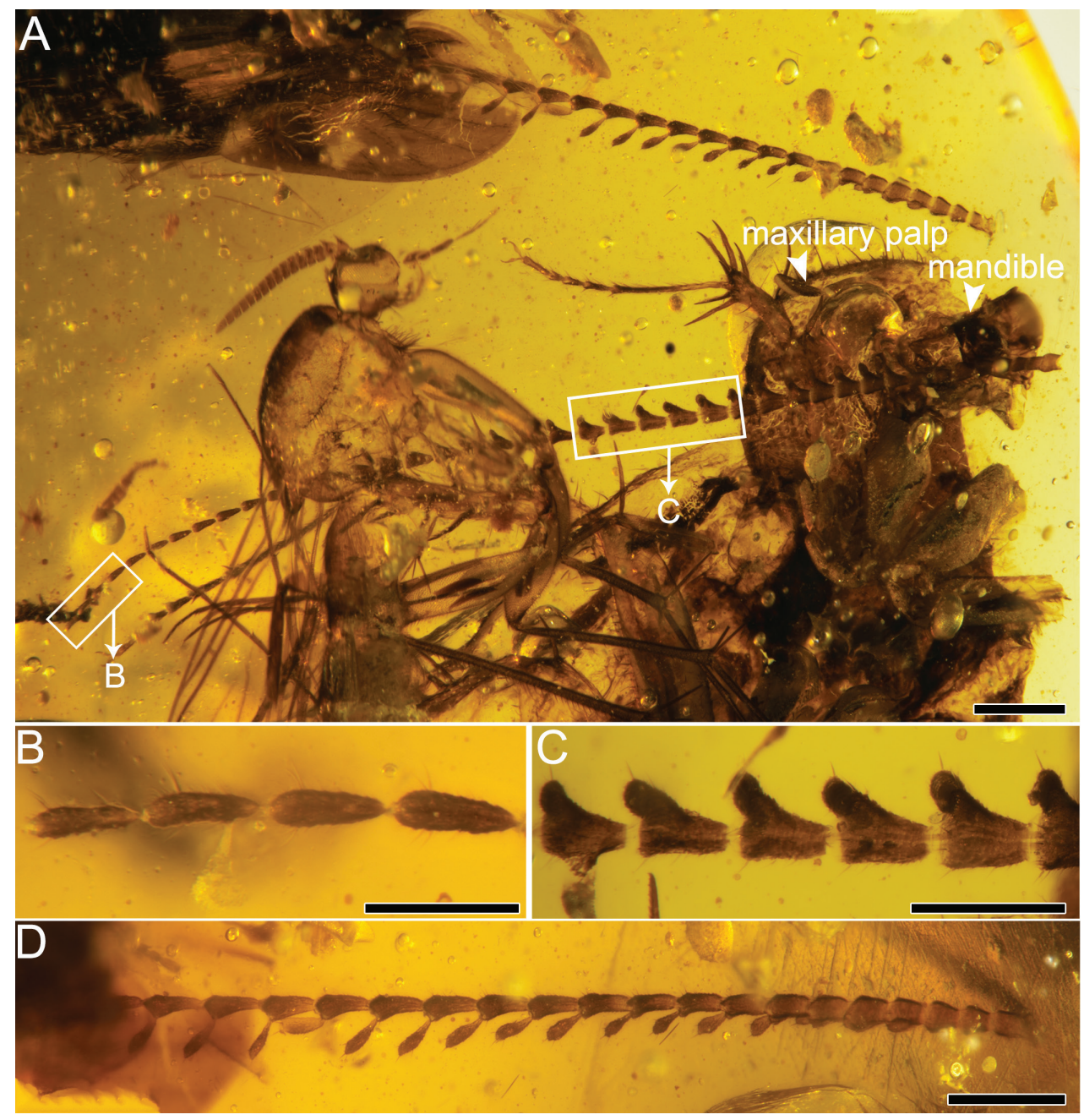

Figure 3. Holotype of Fragosublatta pectinata gen. et sp. nov. CNU-BLA-MA2015001 A photograph of the two antennae, with arrowheads indicating the maxillary palp and the mandible $\mathbf{B}$ the apical section of the longer antenna $\mathbf{C}$ the medial section of the longer antenna $\mathbf{D}$ photograph of the shorter antenna. Scale bars: $0.5 \mathrm{~mm}(\mathbf{A}), 0.1 \mathrm{~mm}(\mathbf{B}, \mathbf{C}), 0.25 \mathrm{~mm}(\mathbf{D})$.

$0.60 \mathrm{~mm}$ ) with terminal spine $0.29 \mathrm{~mm}$ long (Fig. 4C). Tibia longer (length $3.08 \mathrm{~mm} /$ width $0.28 \mathrm{~mm}$ ) with at least 10 spurs. Tarsi five-segmented (tarsomeres $1-5$ lengths $0.82-0.39-0.37-0.36-0.41 \mathrm{~mm}$ ) but narrow (width $0.07 \mathrm{~mm}$ ). Plantulae present at four proximal tarsomeres in fore and mid tarsi, which also exist in third and fourth tarsomeres of hind leg. First and second hind tarsomeres apparently have spines, but lack plantulae (Fig. 4A, D, E). Six sternites visible on abdomen, with sparse chaetae. Cercus moniliform, completely preserved with up to $0.23 \mathrm{~mm}$ long sensilla chaetica, divided into eight cercomeres on left $(\mathrm{ca} 1.51 \mathrm{~mm})$ and nine on right $(\mathrm{ca} 1.73 \mathrm{~mm})$, basally thicker and apically narrower (Fig. 1D). Hind margin of subgenital plate con- 

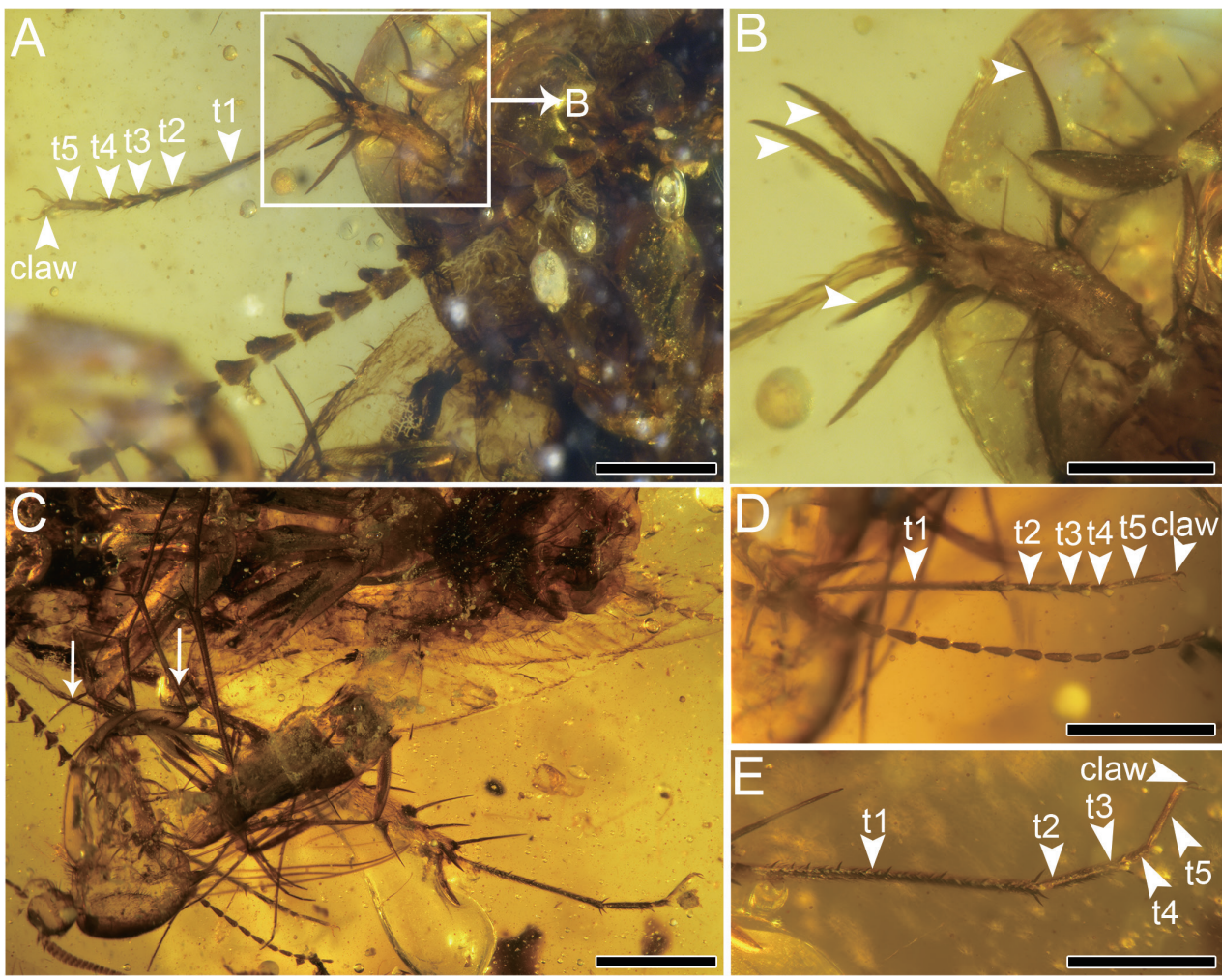

Figure 4. Holotype of Fragosublatta pectinata gen. et sp. nov. CNU-BLA-MA2015001 A photograph of the foreleg $\mathbf{B}$ details of the foretibia spurs, with arrowheads indicating the serration $\mathbf{C}$ photograph of the midleg and hind leg, with arrowheads indicating the terminal spines $\mathbf{D}$ photograph of the midtarsus E photograph of the hind tarsus. Scale bars: $0.5 \mathrm{~mm}(\mathbf{A}, \mathbf{C}), 0.25 \mathrm{~mm}(\mathbf{B}, \mathbf{D}, \mathbf{E})$.

vex, setose, with a wide concave incision medially. Styli asymmetrical, left stylus longer (length $0.35 \mathrm{~mm}$ ) than right stylus $(0.16 \mathrm{~mm}$ long). Both styli unsegmented.

Etymology. The name pectinata is derived from the Latin word of pectinatus referring to the pectinate antennae.

Remarks. The antennae are detached from the head of Fragosublatta pectinata gen. et sp. nov., but the basal antennomeres of both antennae are close to the head (Fig. 3A). As shown in Figs 1B and 2B, the length of the left antennae, as preserved, is slightly shorter than the forewing length, which is consistent with the length ratios of the antennae/forewing for many documented fossil cockroaches (Liang et al. 2019). Therefore, we have high confidence that these two antennae belong to Fragosublatta pectinata gen. et sp. nov. based on these observations. Besides, there are two syninclusions in this amber piece, including a Mycetophiloidea Diptera and a Hemiptera 'Homoptera' (suspected) close to the hind legs of the new species. Due to poor preservation, we cannot identify the detailed taxonomic classification for these two syninclusions. 


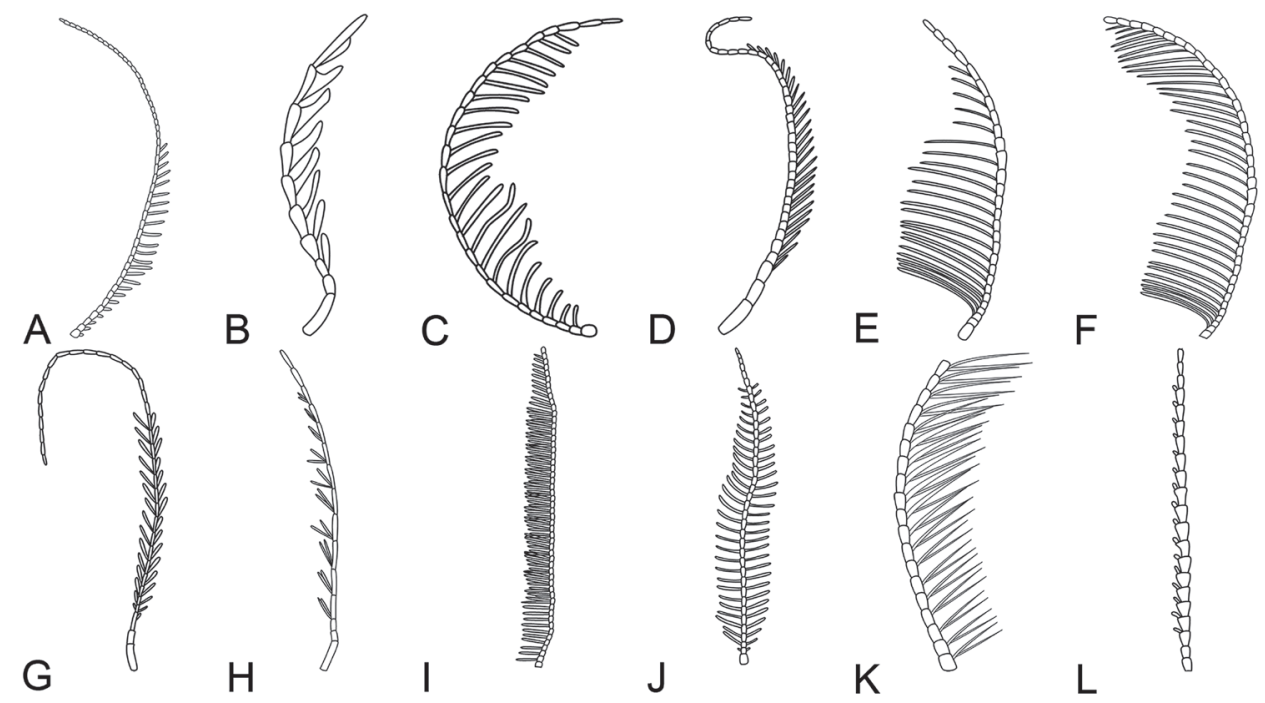

Figure 5. Line drawings of ramified antennae from insects of different orders $\mathbf{A}$ the pectinate antenna of Mecoptera (Vitimopsyche pectinella) B the pectinate antenna of Coleoptera (Cerophytum albertalleni) C the pectinate antenna of Neuroptera (Cretodilar burmanus) D the pectinate antenna of Hymenoptera (Jibaissodes peichenae) $\mathbf{E}$ the plumose antenna of Hymenoptera (Jibaissodes bellus) $\mathbf{F}$ the flabellate antenna of Hymenoptera (Atefia rasnitsyni) $\mathbf{G}$ the bipectinate antenna of Trichoptera (Bipectinata orientalis) $\mathbf{H}$ the bipectinate antenna of Trichoptera (Palaeopsilotreta burmanica) I the bipectinate antenna of Trichoptera (Cathayamodus fournieri) $\mathbf{J}$ the bipectinate antenna of Neuroptera (Cretogramma engeli) $\mathbf{K}$ the bipectinate antenna of Blattodea (Ol xiai) L The pectinate antenna of Blattodea (Fragosublatta pectinata gen. et sp. nov.).

\section{Discussion}

The new genus and species, Fragosublatta pectinata gen. et sp. nov., displays distinctive comb-like extensions of pectinate antennae. This antennal modification of comb-like extensions also occurs among Cretaceous fossils of other insect orders, such as Trichoptera, Mecoptera, Hymenoptera, Coleoptera and Neuroptera (Table 2, Fig. 5). Nevertheless, there are some differences in the number and the length of comb-like extensions of pectinate or bipectinate flagellomeres. Other than the fossil insect orders mentioned above, pectinate or bipectinate antennae are known in extant insect orders, for example, Diptera (Keroplatidae, Ditomyiidae), Lepidoptera (Lymantridae, Saturniidae, etc.) and Megaloptera (Corydalidae) (Ševčík 2000; Tegoni et al. 2004; Liu and Yang 2006; Symonds et al. 2011; Ševčík et al. 2015). This new finding of pectinate antennae for a cockroach in the mid-Cretaceous, in conjunction with the other 26 fossil insects in six orders (Table 2), provides further evidence to support structural convergent evolution for ramified antennae among different insect lineages. The most direct effect of the ramified antennal structure to enhance insect sensing is the overall expansion of the antenna surface area and the corresponding increase in the number of receptors (Gao et al. 2016). Since there are only two reported male cockroaches with pectinate or 
Table 2. Ramified antennal types of different insect orders in the Cretaceous.

\begin{tabular}{|c|c|c|c|c|c|}
\hline Order & Antennal type & Family & Species & Locality & Reference \\
\hline \multirow[t]{2}{*}{ Mecoptera } & pectinate & Mesopsychidae & Vitimopsyche pectinella & China & Gao et al. 2016 \\
\hline & pectinate & Mesopsychidae & Vitimopsyche kozlovi & China & Ren et al. 2009 \\
\hline \multirow[t]{5}{*}{ Trichoptera } & bipectinate & Calamoceratidae & Bipectinata orientalis & Myanmar & Wichard et al. 2020 \\
\hline & bipectinate & Odontoceridae & Palaeopsilotreta cretacea & Myanmar & Wichard et al. 2020 \\
\hline & bipectinate & Odontoceridae & Palaeopsilotreta burmanica & Myanmar & Wichard et al. 2020 \\
\hline & bipectinate & Odontoceridae & Palaeopsilotreta xiai & Myanmar & Wichard et al. 2020 \\
\hline & bipectinate & Incertae sedis & Cathayamodus fournieri & China & Gao et al. 2016 \\
\hline \multirow[t]{3}{*}{ Hymenoptera } & pectinate & Megalodontesidae & Jibaissodes peichenae & China & Wang et al. 2019 \\
\hline & plumose & Megalodontesidae & Jibaissodes bellus & China & Gao et al. 2016 \\
\hline & flabellate & Incertae sedis & Atefia rasnitsyni & Brazil & Krogmann et al. 2013 \\
\hline \multirow[t]{6}{*}{ Coleoptera } & pectinate & Cerophytidae & Cerophytum albertalleni & Myanmar & Yu et al. 2019 \\
\hline & pectinate & Brachypsectridae & Vetubrachypsectra burmitica & Myanmar & Qu et al. 2019 \\
\hline & pectinate & Lycidae & Prototrichalus sepronai & Myanmar & Molino-Olmedo et al. 2020 \\
\hline & pectinate & Cantharidae & Burmomiles willerslevorum & Myanmar & Fanti et al. 2018 \\
\hline & pectinate & Cantharidae & Sanaungulus curtipennis & Myanmar & Fanti et al. 2018 \\
\hline & pectinate & Cantharidae & Sanaungulus ghitaenoerbyae & Myanmar & Fanti et al. 2018 \\
\hline \multirow[t]{9}{*}{ Neuroptera } & bipectinate & Incertae sedis & Oligopsychopsis penniformis & Myanmar & Chang et al. 2017 \\
\hline & bipectinate & Kalligrammatidae & Burmogramma liui & Myanmar & Liu et al. 2018 \\
\hline & bipectinate & Kalligrammatidae & Burmopsychops labandeirai & Myanmar & Liu et al. 2018 \\
\hline & bipectinate & Kalligrammatidae & Cretogramma engeli & Myanmar & Liu et al. 2018 \\
\hline & bipectinate & Kalligrammatidae & Oligopsychopsis grandis & Myanmar & Liu et al. 2018 \\
\hline & pectinate & Dilaridae & Cretanallachius magnificus & Myanmar & Huang et al. 2015 \\
\hline & pectinate & Dilaridae & Cretadilar olei & Myanmar & Makarkin 2016 \\
\hline & pectinate & Dilaridae & Burmopsychops groehni & Myanmar & Makarkin 2016 \\
\hline & pectinate & Dilaridae & Cretodilar burmanus & Myanmar & Liu et al. 2016 \\
\hline Blattodea & bipectinate & Olidae & Olxiai & Myanmar & Vršanský and Wang 2017 \\
\hline
\end{tabular}

bipectinate antennae, potential sexual dimorphism for mid-Cretaceous cockroaches is suggested, pending future reports of more examples and conspecific females.

The fore tibia spurs of the new species have serrations on their inner surface, which is special among cockroaches (Fig. 4B). To our best knowledge, only Nodosigalea burmanica (Corydiidae) possesses similar serrations in Burmese amber ( $\mathrm{Li}$ and Huang 2018). Besides, the tarsal plantulae in fore and mid legs are usually considered as adhesive devices allowing the cockroach to perch or forage on leaves, while the tarsal spines on hind legs are supposed to help the cockroach with rapid movement (Bell et al. 2007).

In addition, the venation and cercus of the new species are also interesting. In the right forewing, there are two incomplete $\mathrm{CuA}$ and $\mathrm{A}$ (Fig. 2C). This character has been reported in the Raphidiomimidae (Liang et al. 2009). It is likely that this phenomenon was due to the fusion of veins. The basal part of cercus for this new species is cylindrical while the terminal part is moniliform. The function or derivation of this structure of the cercus are unknown, pending future research with new fossil specimens.

\section{Conclusions}

This study documents and reports a new species of cockroach, Fragosublatta pectinata gen. et sp. nov., assigned to the Corydiidae. The pectinate antennae of this new species 
have been compared to 26 other ramified antennal structures in six orders of insects in the Cretaceous. This finding enriches the diversity of morphological characters of cockroaches and suggests that some extinct representatives of this family might have had sexual dimorphism in their antennae. Furthermore, diversified structures of ramified antennae in different orders of fossil insects during the Cretaceous provide further evidence supporting the convergent evolution of antennal structures among different insect lineages.

\section{Acknowledgements}

We thank the Editorial Board of ZooKeys and express our gratitude to Dr Fred Legendre, Dr André Nel, Dr Christopher Glasby and Lucia Šmídová for critical and valuable reviews of the manuscript. D.R. was supported by grants from the National Natural Science Foundation of China (No. 31730087 and 32020103006). The authors declare no competing interests.

\section{References}

Bell WJ, Nalepa CA, Roth LM (2007) Cockroaches: Ecology, Behavior, and Natural History. Johns Hopkins University Press, Baltimore, 230 pp.

Chang Y, Fang H, Shih CK, Ren D, Wang YJ (2017) Reevaluation of the subfamily Cretanallachiinae Makarkin, 2017 (Insecta: Neuroptera) from Upper Cretaceous Myanmar amber. Cretaceous Research 84: 533-539. https://doi.org/10.1016/j.cretres.2017.10.028

Chen T, Xu CP, Chen L (2020) A new cockroach (Insecta: Blattaria: Liberiblattinidae) from mid-Cretaceous Burmese amber. Acta Palaeontologica Sinica 59(1): 64-69. https://doi. org/10.19800/j.cnki.aps.2020.01.08

Fanti F, Damgaard AL, Ellenberger S (2018) Two new genera of Cantharidae from Burmese amber of the Hukawng Valley (Insecta, Coleoptera). Cretaceous Research 86: 170-177. https://doi.org/10.1016/j.cretres.2018.02.015

Gao TP, Shih CK, Labandeira CC, Santiago-Blay JA, Yao YZ, Ren D (2016) Convergent evolution of ramified antennae in insect lineages from the Early Cretaceous of northeastern China. Proceedings of the Royal Society B: Biological Sciences 283: e20161448. https:// doi.org/10.1098/rspb.2016.1448

Grimaldi DA, Ross AJ (2004) Raphidiomimula, an enigmatic new cockroach in cretaceous amber from Myanmar (Burma) (Insecta: Blattodea: Raphidiomimidae). Journal of Systematic Palaeontology 2(2): 101-104. https://doi.org/10.1017/S1477201904001142.

Grimaldi DA, Ross AJ (2017) Extraordinary Lagerstätten in amber, with particular reference to the Cretaceous of Burma. In: Fraser NC, Sues HD (Eds) Terrestrial Conservation Lagerstätten: Windows into the Evolution of Life on Land. Dunedin Press, Edinburgh, 287-342.

Hinkelman J (2019) Spinaeblattina myanmarensis gen. et sp. nov. and Blattoothecichnus argenteus ichnogen. et ichno sp. nov. (both Mesoblattinidae) from mid-Cretaceous Myanmar amber. Cretaceous Research 99: 229-239. https://doi.org/10.1016/j.cretres.2019.02.026 
Hinkelman J, Vršanská L (2020) A Myanmar amber cockroach with protruding feces contains pollen and a rich microcenosis. The Science of Nature 107(13): 1-19. https://doi. org/10.1007/s00114-020-1669-y

Hinkelman J (2020) Earliest behavioral mimicry and possible food begging in a Mesozoic alienopterid pollinator. Biologia 75: 83-92. https://doi.org/10.2478/s11756-019-00278-z

Huang DY, Azar D, Cai CY, Garrouste R, Nel A (2015) The first Mesozoic pleasing lacewing (Neuroptera: Dilaridae). Cretaceous Research 56: 274-277. http://dx.doi.org/10.1016/j. cretres.2015.06.001

Inward D, Beccalon G, Eggleton P (2007) Death of an order: a comprehensive molecular phylogenetic study confirms that termites are eusocial cockroaches. Biology Letters 3(3): 331-335. https://doi.org/10.1098/rsbl.2007.0102

Koubová I, Mlynský T (2020) Two new mid-Cretaceous dictyopterans (Umenocoleidae: Vitisminae) from northern Myanmar exemplify taphonomic bias. Amba Projekty 10(1): 1-16.

Krogmann L, Engel MS, Bechly G, Nel A (2013) Lower Cretaceous origin of long-distance mate finding behaviour in Hymenoptera (Insecta), Journal of Systematic Palaeontology 11(1): 83-89. http://doi.org/10.1080/14772019.2012.693954

Li JX, Zhao XD, Gao YP, Wang B, Xiao CX (2020) Cockroach Stavba jarzembowskii sp. nov. (Blattaria: Liberiblattindae) from mid-Cretaceous Burmese amber. Cretaceous Research 115: e104531. https://doi.org/10.1016/j.cretres.2020.104531

Li XR, Wang ZQ (2017) Updating the knowledge of assassin bug cockroaches (Blattodea: Blaberidae: Paranauphoeta Brunner von Wattenwyl): Species from China and taxonomic changes. Entomological Science 20: 302-317. http://doi.org/10.1111/ens.12258.

Li XR, Huang DY (2018) A new Cretaceous cockroach with heterogeneous tarsi preserved in Burmese amber (Dictyoptera, Blattodea, Corydiidae). Cretaceous Research 92: 12-17. https://doi.org/10.1016/j.cretres.2020.104383

Li XR, Huang DY (2019) A new mid-Cretaceous cockroach of stem Nocticolidae and reestimating the age of Corydioidea (Dictyoptera: Blattodea). Cretaceous Research 106: e104202. https://doi.org/10.1016/j.cretres.2019.104202

Li XR, Huang DY (2021) A brachypterous cockroach (Dictyoptera: Blattaria: Blattoidea) and its potential relevance to the palaeoenvironment of mid-Cretaceous Myanmar amber locality. Cretaceous Research 120: e104730. http://doi.org/10.1016/j.cretres.2020.104730.

Liang JH, Vršanský P, Ren D, Shih CK (2009) A new Jurassic carnivorous cockroach (Insecta, Blattaria, Raphidiomimidae) from the Inner Mongolia in China. Zootaxa 1974: 17-30.

Liang JH, Shih CK, Ren D (2019) Blattaria - Cockroaches. Chapter 7. In: Ren D, Shih CK, Gao T, Yao Y, Wang Y (Eds) Rhythms of Insect Evolution: Evidence from the Jurassic and Cretaceous in Northern China. John Wiley \& Sons Ltd, 91-112. https://doi. org/10.1002/9781119427957.ch7

Ren D, Shih CK, Gao TP, Wang YJ, Yao YZ (2019) Rhythms of Insect Evolution: Evidence from the Jurassic and Cretaceous of Northern China Wiley-Blackwell, New York, 710 pp. https://doi.org/10.1002/9781119427957

Liu Q, Lu XM, Zhang QQ, Chen J, Zheng XT, Zhang WW, Liu XY, Wang B (2018) High niche diversity in Mesozoic pollinating lacewings. Nature Communications 9: e3793. https://doi.org/10.1038/s41467-018-06120-5 
Liu X, Yang D (2006) Revision of the fishfly genus Ctenochauliodes van der Weele (Megaloptera, Corydalidae). Zoologica Scripta 35: 473-490. https://doi.org/10.1111/j.14636409.2006.00240.x

Liu XY, Aspock H, Winterton S, Zhang WW, Aspock U (2016) Phylogeny of pleasing lacewings (Neuroptera: Dilaridae) with a revised generic classification and description of a new subfamily. Systematic Entomology 42: 448-471. https://doi.org/10.1111/syen.12225

Makarkin VN (2016) New taxa of unusual Dilaridae (Neuroptera) with siphonate mouthparts from the mid-Cretaceous Burmese amber. Cretaceous Research 74: 11-22. http://dx.doi. org/10.1016/j.cretres.2016.12.019

Mlynský T, Wu H, Koubová I (2019) Dominant Burmite cockroach Jantaropterix ellenbergeri sp. n. might laid isolated eggs together. Palaeontographica Abteilung A 314(1-3): 69-79. https://doi.org/10.1127/pala/2019/0091

Molino-Olmedo F, Ferreira VS, Branham MA, Ivie MA (2020) The description of Prototrichalus gen. nov. and three new species from Burmese amber supports a mid-Cretaceous origin of the Metriorrhynchini (Coleoptera, Lycidae). Cretaceous Research 111: e104452. https://doi.org/10.1016/j.cretres.2020.104452

Podstrelená L, Sendi H (2018) Cratovitisma Bechly, 2007 (Blattaria:Umenocoleidae) recorded in Lebanese and Myanmar ambers. Palaeozoology-Stratigraphy 310(3-6): 121-129. https://doi.org/10.1127/pala/2018/0076

Qiu L, Wang ZQ, Che YL (2019a) First record of Blattulidae from mid-Cretaceous Burmese amber (Insecta: Dictyoptera). Cretaceous Research 99: 281-290. https://doi.org/10.1016/j. cretres.2019.03.011

Qiu L, Wang ZQ, Che YL (2019b) A new corydiid cockroach with large holoptic eyes in Upper Cretaceous Burmese amber (Blattodea: Corydiidae: Euthyrrhaphinae). Cretaceous Research 96: 179-183. https://doi.org/10.1016/j.cretres.2018.12.018

Qiu L, Liu YC, Wang ZQ, Che YL (2020) The first blattid cockroach (Dictyoptera: Blattodea) in Cretaceous amber and the reconsideration of purported Blattidae. Cretaceous Research 109: e104359. https://doi.org/10.1016/j.cretres.2019.104359

Qu TQ, Yin ZW, Huang DY, Cai CY (2019) First Mesozoic brachypsectrid beetles in midCretaceous amber from northern Myanmar (Coleoptera: Elateroidea: Brachypsectridae). Cretaceous Research 106: e104190. https://doi.org/10.1016/j.cretres.2019.07.020

Rehn JWH (1951) Classification of the Blattaria as indicated by their wings (Orthoptera). Memoirs of the American Entomological Society 14: 1-134.

Ren D, Labandeira CC, Santiago-Blay JA, Rasnitsyn A, Shih CK, Bashkuev A, Logan MAV, Hotton CL, Dilcher D (2009) A Probable Pollination Mode Before Angiosperms: Eurasian, Long-Proboscid Scorpionflies. Science 326(5954): 840-847. https://doi.org/10.1126/science. 1178338

Ross AJ (2012) Testing decreasing variabililty of cockroach forewings through time using four Recent species: Blattella germanica, Polyphaga aegyptiaca, Shelfordella lateralis and Blaberus craniifer, with implications for the study of fossil cockroach forewings. Insect Science 19: 129-142. https://doi.org/10.1111/j.1744-7917.2011.01465.x

Ross AJ (2020) Supplement to the Burmese (Myanmar) amber checklist and bibliography. Palaeoentomology 3(1): 103-118. https://doi.org/10.11646/palaeoentomology.3.1.14 
Ross AJ (2021) Supplement to the Burmese (Myanmar) amber checklist and bibliography. Palaeoentomology 4(1): 57-76. https://doi.org/10.11646/palaeoentomology.4.1.11.

Roth LM (2003) Systematics and phylogeny of cockroaches (Dictyoptera: Blattaria). Oriental Insects 37: 1-186. http://doi.org/10.1080/003-5316.2003.10417344.

Schneider D (1964) Insect antennae. Annual. Review of Entomology 9: 103-122. https://doi. org/10.1146/annurev.en.09.010164.000535

Sendi H, Hinkelman J, Vršanská L, Kúdelová T, Kúdela M, Zuber M, Kamp T, Vršanský P (2020a) Roach nectarivory, gymnosperm and earliest flower pollination evidence from Cretaceous ambers. Biologia 75: 1613-1630. https://doi.org/10.2478/s11756-019-00412-x

Sendi H, Vršanský P, Podstrelená L, Hinkelman J, Kúdelová T, Kúdela M, Vidlička L, Ren XJ, Quicke DLJ (2020b) Nocticolid cockroaches are the only known dinosaur age cave survivors. Gondwana Research 82: 288-298. https://doi.org/10.1016/j.gr.2020.01.002

Ševč́k J (2000) A new species of Symmerus from Laos (Diptera: Ditomyiidae). Entomological Problems 31(2): 181-182.

Ševčík J, Mantic M, Blagoderov V (2015) Two new genera of Keroplatidae (Diptera), with an updated key to the World genera of Keroplatini. Zoobank 55(1): 387-399.

Smart J (1951) The wing-venation of the American cockroach Periplaneta americana Linn. (Insecta: Blattidae). Proceedings of the Zoological Society of London 121: 501-509. https:// doi.org/10.1111/j.1096-3642.1951.tb00750.x

Šmídová L, Lei XJ (2017) The earliest amber-recorded type cockroach family was aposematic (Blattaria: Blattidae). Cretaceous Research 72: 189-199. http://dx.doi.org/10.1016/j.cretres.2017.01.008

Šmídová L (2020) Cryptic bark cockroach (Blattinae: Bubosa poinari gen. et sp. nov.) from mid-Cretaceous amber of northern Myanmar. Cretaceous Research 109: 104383. https:// doi.org/10.1016/j.cretres.2020.104383

Snodgrass RE (1935) Principles of Insect Morphology. McGraw-Hill Book Company, New York and London, $667 \mathrm{pp}$.

Symonds MRE, Johnson TL, Elgar MA (2011) Pheromone production, male abundance, body size, and the evolution of elaborate antennae in moths. Ecology and Evolution 2(1): 227246. https://doi.org/10.1002/ece3.81

Tegoni M, Campanacci V, Cambillau C (2004) Structural aspects of sexual attraction and chemical communication in insects. Trends in Biochemical Sciences 29(5): 257-263. https://doi.org/10.1016/j.tibs.2004.03.003

Vršanský P, Vidlička L, Barna P, Bugdaeva E, Markevich V (2013) Paleocene origin of the cockroach families Blaberidae and Corydiidae: Evidence from Amur River region of Russia. Zootaxa 3635: 117-126. https://doi.org/10.11646/zootaxa.3635.2.2

Vršanský P, Bechly G (2015) New predatory cockroaches (Insecta: Blattaria: Manipulatoridae fam.n.) from the Upper Cretaceous Myanmar amber. Geologica Carpathica 66(2): 133-138. https://doi.org/10.1515/geoca-2015-0015

Vršanský P, Wang B (2017) A new cockroach, with bipectinate antennae, (Blattaria: Olidae fam. nov.) further highlights the differences between the Burmite and other faunas. Biologia 72(11): 1327-1333. http://doi.org/10.1515/biolog-2017-0144 
Vršanský P, Bechly G, Zhang QQ, Jarzembowski EA, Mlynský T, Šmídová L, Barna P, Kúdela M, Aristov D, Bigalk S, Krogmann L, Li LQ, Zhang Q, Zhang HC, Ellenberger S, Müller P, Gröhn C, Xia FY, Ueda K, Vd’ačný P, Valaška D, Vršanská L, Wang B (2018a) Batesian insect-insect mimicry-related explosive radiation of ancient alienopterid cockroaches. Biologia 73: 987-1006. https://doi.org/10.2478/s11756-018-0117-3

Vršanský P, Šmídová L, Sendi H, Barna P, Müller P, Ellenberger S, Wu H, Ren XY, Lei XJ, Azar D, Šurka J, Su T, Deng WYD, Shen XH, Lv J, Bao T, Bechly G (2018b) Parasitic cockroaches indicate complex states of earliest proved ants. Biologia 74: 65-89. https://doi. org/10.2478/s11756-018-0146-y.

Vršanský P, Vršanská L, Beňo M, Bao T, Lei XJ, Ren XJ, Wu H, Šmídová L, Bechly G, Jun L, Yeo M, Jarzembowski E (2019) Pathogenic DWV infection symptoms in a Cretaceous cockroach. Palaeontographica Abteilung A 314(1-3): 1-10. https://doi.org/10.1127/ pala/2019/0084

Vršanský P, Sendi H, Hinkelman J, Hain M (2021) Alienopterix Mlynský et al., 2018 complex in North Myanmar amber supports Umenocoleoidea/ae status. Biologia 76: 2207-2224. https://doi.org/10.1007/s11756-021-00689-x

Wang YM, Wang M, Shih CK, Rasnitsyn AP, Yao J, Ren D, Gao TP (2019) A new sawfly of Megalodontesidae (Insecta, Hymenoptera, Pamphilioidea) with pectinate antennae from the Early Cretaceous of China. ZooKeys 893: 115-123. http://doi.org/10.3897/zookeys.893.38512

Wichard W, Espeland M, Muller P, Wang B (2020) New species of caddisflies with bipectinate antennae from Cretaceous Burmese amber (Insecta, Trichoptera: Odontoceratidae, Calamoceratidae). European Journal of Taxonomy 653: 1-17. https://doi.org/10.5852/ ejt.2020.653

Yu YL, Slipinski A, Lawrence JF, Yan E, Ren D, Pang H (2019) Reconciling past and present: Mesozoic fossil record and a new phylogeny of the family Cerophytidae (Coleoptera: Elateroidea). Cretaceous Research 99: 51-70. https://doi.org/10.1016/j.cretres.2019.02.024

Zhao ZP, Yin XC, Shih CK, Gao TP, Ren D (2019) Termite colonies from mid-Cretaceous Myanmar demonstrate their early eusocial lifestyle in damp wood. National Science Review 7(2): 381-390. https://doi.org/10.1093/nsr/nwz141 